\title{
Significance of Social Science Mainstreaming for Sustainable Conservation of Natural Resources
}

\author{
Keshab Thapa* and Shirley Thompson \\ University of Manitoba, Canada
}

Submission: February 08, 2017; Published: February 14, 2017

"Corresponding author: Keshab Thapa, University of Manitoba, Natural Resources Institute, 70 Dysart Rd, Treaty 1 \& Metis Homeland, Winnipeg, R3T 2N2, Canada, Tel: +1 (431) 777 6048; Email: thapak@myumanitoba.ca

\section{Opinion}

Conservation initiatives around the globe aim to improve livelihoods of the poor through sustainable conservation of natural resources [1-3]. But, these initiatives, in many instances, are guided by the theories and know-how of natural science with less attention to social issues without taking into account social science expertise and participatory processes for the conservation of natural resources $[4,5]$. Consequently, interdisciplinary research by mainstreaming social science is important for sustainable conservation of natural resources.

Mainstreaming social science strengthens conservation initiatives to ensure sustainable use of resources through peoples' participation. Because the skills, expertise and knowledge of social scientists [6] help improve public understanding of conservation policy and practice by pursuing the critical questions [4]. Besides, social science generates evidence for an appropriate governance of conservation that transforms conventional tenets of conservation [4]. Thus, social science mainstreaming socializes conservation to appropriately interpret community needs that prioritize to people-driven sustainable conservation.

Notwithstanding, natural scientists may argue that social science mainstreaming may not bring a solution to all conservation issues. That is why social scientists and natural scientists should work closely in a trans-disciplinary team to jointly design conservation objectives to work together from the initial planning stages of the project cycle to its conclusion [4]. Therefore, the ideological, institutional, knowledge, and capacity barriers for mainstreaming social science in conservation should be addressed to facilitate meaningful interaction and collaboration between social scientists and natural scientists, and interaction of social scientists with trans-disciplines [4].

Mainstreaming social science in conservation would foster adaptive management including monitoring, evaluation and communicating findings regarding conservation initiatives to improve public policy and programming. For instance, social scientists are given an important role in tracking and monitoring of the United Nations Sustainable Development [7,8]. Social science mainstreaming should be prioritized by conservation scientists and in conservation programs, institutions, and global conservation policies at the local to global scale [4]. Thus, institutional commitments and allocation of funding would enable social scientists to mainstream livelihoods, poverty, and other social issues in conservation.

The world in the twenty first century is more committed to reducing hunger and poverty for a more equitable and peaceful society [3]. Conservation and sustainable use of natural resources contributes to reducing poverty in developing world and contributes to improving quality of living in the developed world. However, ensuring that the conservation benefits are realized in an equitable manner requires proper assessment of social issues such as social inequalities, peoples' needs, aissues causing conflict, access to and control over resources, representation, decision-making processes, etc. The results of such assessments facilitate an integration of pragmatic solutions in the conservation programs Hossain et al. [1]. Better outcomes to reduce poverty and achieve sustainability are achieved when social science is mainstreamed at all tiers of conservation of natural resources and environment [3].

\section{References}

1. Hossain BMS, Rahman M, Thompson S, Rashed-Un-Nabi M, Kibria M (2013) Climate Change Resilience Assessment Using Livelihood Assets of Coastal Fishing Community in Nijhum Dwip, Bangladesh. Pertanika Journal of Science \& Technology 21(2): 397-422

2. Rahman, Uddin RS, Thompson S (2012) Effective Governance Strategy: Key to Sustainable Collaborative Management in a Wildlife Sanctuary in South-Eastern part of Bangladesh. International Journal of Environmental and Rural Development 3(2): 174-180.

3. United Nations (2015) Transforming out world: the 2030 agenda for sustainable development. United Nations. 
4. Bennett NJ, Roth R, Klain SC, Chan KMA, Clark DA, et al. (2017) Mainstreaming the social science in conservation. Conserv Biol 31(1): 56-66.

5. Ojha HR, Paudel NS, Banjade MR, McDougall C, Cameroon J (2010) The deliberate scientists: Integrating science and politics in forest resource governance in Nepal. In German L, et al. (Eds.), Knowledge, culture, and power in agriculture and natural resource management, Springer Science+Business Media, UK, pp. 167-191.

6. German L, Verma R, Ramisch JJ (2010) Agriculture, natural resource management, and development beyond biophysical. In German L, et al. (Eds.), Knowledge, culture, and power in agriculture and natural resource management, Springer Science+Business Media, UK, p. 1-21.

7. Hajer M, Nilsson M, Raworth K, Bakker P, Berkhout F, et al. (2015) Beyond cockpit-ism: Four insights to enhance the transformative potential of the sustainable development goals. Sustainability $7(2)$ : $1651-1660$

8. Lu Y, Nakicenovic N, Visbeck M, Stevance AS (2015) Policy: Five priorities for the UN Sustainable Development Goals. Nature 520(7548): 432-433.

\section{Your next submission with Juniper Publishers will reach you the below assets}

- Quality Editorial service

- Swift Peer Review

- Reprints availability

- E-prints Service

- Manuscript Podcast for convenient understanding

- Global attainment for your research

- Manuscript accessibility in different formats

( Pdf, E-pub, Full Text, Audio)

- Unceasing customer service

Track the below URL for one-step submission https://juniperpublishers.com/online-submission.php 